\title{
Medial Longitudinal Fasciculus Acute Ischemic Changes may be Missed During Imaging
}

\section{Medial Longitunal Fasikül Akut İskemik Değişiklikleri Görüntülemede Gözden Kaçabilir}

Ertan SÖNMEZ1 is, Abuzer ÖZKAN¹ id, Emin NASIROV², Bedia GÜLEN¹ id

'Department of Emergency Medicine, Bezmialem Vakif University School of Medicine, İstanbul, Turkey

${ }^{2}$ Department of Neurology, Bezmialem Vakif University School of Medicine, İstanbul, Turkey

\section{ABSTRACT}

The medial longitudinal fasciculus (MLF) is a pair of crossed fibers of axons, on each side of the brainstem that carries information about the direction of eye movement. An ischemic stroke is the most common cause of MLF syndrome. We report a patient with unilateral partial oculomotor paresis associated with internuclear ophthalmoplegia, which is a dysfunction of the MLF in the pontine. A second diffusion-weighted magnetic resonance imaging (DW-MRI) showed a high-signal-intensity lesion in the brainstem. We would like to emphasize that detailed neurological physical examination and imaging control are essential aspects of clinical assessment for the diagnosis of MLF infarction because its detection based on imaging is challenging.

Keywords: Partial oculomotor paresis, brainstem, MLF, MRI

\section{öz}

Medial longitunal fasikül (MLF) beyin sapının her iki tarafına gözlerin hareket yönü hakkında bilgi taşıyan bir çift akson lifidir. İskemik inme MLF sendromunun en yaygın görülen nedenidir. Biz çekirdekler arası oftalmoplejili tek taraflı parsiyel okulomotor parezinin eşlik ettiği ponsun MLF bozukluğunu bir hastada sunuyoruz. DW-MRI'da beyin sapında aşikar yüksek sinyal görüntülü lezyon görüldü. Görüntülemede ki zorluğu nedeniyle MLF lezyonlarını tanımada, detaylı nörolojik muayene ve görüntüleme tekrarının önemini vurgulamak istedik.

Anhatar Kelimeler: Parsiyel okulomotor parezi, beyin sapı, MLF, MRI

\section{Introduction}

The levator palpebrae superioris, pupillary sphincter muscle, and four extraocular muscles (the superior rectus, inferior rectus, medial rectus, and inferior oblique muscles) are innervated by the oculomotor nerve. Internuclear ophthalmoplegia (INO) is characterized by the dysfunction of the medial longitudinal fasciculus (MLF). MLF is a tract that contains axons projecting from the VI nucleus to the medial rectus subnuclei of the contralateral III nuclear complex. Impaired adduction and abducting nystagmus during conjugate version movements are two of the most common findings of INO (1). DWI is the most sensitive for stroke imaging, which is sensitive to the restriction of Brownian motion of extracellular water because of imbalance caused by cytotoxic edema. Generally, water protons have the ability to diffuse extracellularly and lose signal. High intensity on DWI indicates restriction of the ability of water protons to diffuse extracellularly (2). In this case report, we present the radiological and ophthalmologic findings of a patient with MLF infarction and oculomotor paresis in the pons of the brainstem.

\section{Case Report}

An 81-year-old woman with a history of diabetes mellitus complained of diplopia and dizziness in the morning. On physical examination, her blood pressure was $145 / 80 \mathrm{mmHg}$, and her pulse was dysrhythmic with 120 beats per minute. Both eyes showed normal visual acuity, visual fields, color perception, and ocular fundi. Left lateral gaze showed significant strabismus (Figure 1). The right eye had impaired upward and medial gaze. The left eye exhibited normal ocular movements. Both eyes had equal pupillary size $(3.0 \mathrm{~mm})$ and normal light reflexes. Neuro-ophthalmological examination revealed mild palsy of the superior rectus, medial rectus, and inferior oblique muscles. Coordination, reactions, and other cranial nerve reflexes were found to be normal. The plantar reflexes were flexor. Routine laboratory tests revealed no abnormalities. 
The brainstem pontine diffusion restriction was observed in DW-MRI (Figure 2a, b). Chest X-ray imaging and carotid ultrasonography also revealed no abnormalities. Frequent ven-

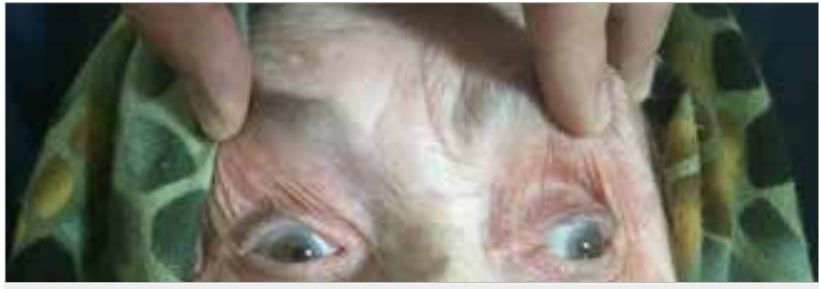

Figure 1. Left lateral gaze showed apparent strabismus
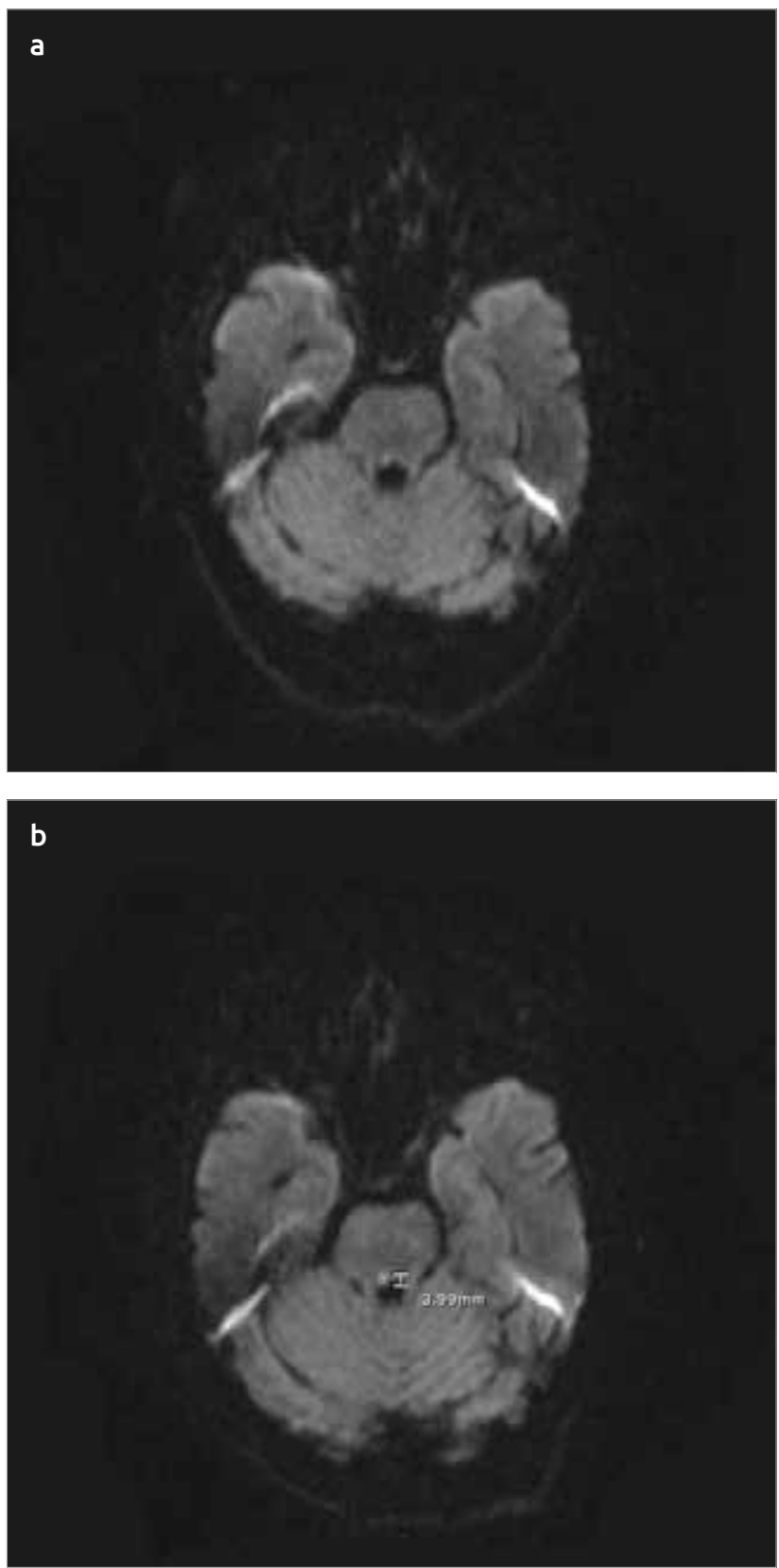

Figure 2. a, b. (a) There was no clear pathological finding. (b) A high-signal-intensity lesion, approximately $4 \mathrm{~mm}$ in diameter, at the level of the right superior cerebellar peduncle of the pons in the brainstem tricular premature beats with sinus tachycardia were observed in electrocardiogram. No cardiac pathology was noted in the transesophageal echocardiography. The patient was diagnosed with partial fascicular oculomotor paresis caused by a pontine stroke affecting the MLF. Clopidogrel sulfate $(75 \mathrm{mg} /$ day, p.o.) treatment was initiated. Incomplete oculomotor nerve paresis continued for one month.

\section{Discussion}

Clinical and radiological findings of a patient with MLF infarction were described in this case report. Impairment of the superior rectus, medial rectus, and inferior oblique muscles was observed upon neuro-ophthalmological examination. Inferior rectus muscles and the pupillary sphincter were protected. Because of presumed microvascular ischemia of the cranial nerves in the presence of atherosclerotic risk factors such as diabetes mellitus, old age, hypertension, and hyperlipidemia, isolated third, fourth, and sixth cranial nerve palsies frequently occur in adults (3). The probability of detecting small lesions that are associated with INO has increased as a result of advancements in neuroimaging. Up to $75 \%$ of all etiologies may have visible lesions (4). Of the patients with presumed brainstem ischemia underlying their INO, a demonstrable lesion on MRI is not found in almost $50 \%$ of the cases (5), while another report showed that only four out of 34 patients did not have a lesion (6). Pupil sphincter fibers are placed on the upper side of the rostrocaudal area and this is followed by inferior rectus, lower oblique, medial rectus, superior rectus and levator palpebra superioris nerve fibers. Thus, oculomotor fascicular fibers that innervate inferior rectus muscles and pupillary sphincter were grouped in the rostral and medial parts, passing through the red nucleus (7). In our patient, the inferior rectus muscles and pupillary sphincter were not impaired as her lesion was in the caudal and lateral region of the oculomotor fascicle on MRI. Patients with diabetes mellitus are known to have pupil sparing oculomotor nerve palsy. Diabetic oculomotor mononeuropathy is a similar finding to oculomotor fascicular infarction. In our patient and in previous patients with oculomotor fascicular infarction, the inferior rectus was protected in addition to normal pupillary reactions $(8,9)$. Johkura (9) stated that the pupillary sphincter and neighboring topography of the inferior rectus muscles play a key role in the discrimination of extramedullary and fascicular oculomotor nerve palsy. It is useful to know the anatomy of the facial anatomy in the diagnosis of ophthalmoparasis.

Based on a variety of factors, including age, associated clinical findings, the pretest probability of identifying a causative lesion, vasculopathic risk factors, and the time and cost of the scan, a formal or informal risk stratification assessment is performed before ordering neuroimaging (10). Although there are continuous advancements in neuroimaging capacities, it is important to recognize that increasing specificity is not always accompanied by ever-increasing sensitivity; thus, as in the first imaging of our patient, conventional MRI may not reveal a causative lesion in early stages (11). Unrelated find- 
ings require further testing or repetition of tests. We can use our knowledge of anatomy and pathophysiology to diagnose patients at high risk for neurological imaging of the underlying severe pathology.

\section{Conclusion}

In this case report, the neuro-ophthalmologic profile and DW-MRI findings of a patient with partial fascicular oculomotor paresis, which was caused by brainstem ischemic stroke were studied. The clinic radiological signs of our patient confirmed that palsy of the medial rectus, superior rectus, and inferior oblique muscles may be caused by MLF damage. For diagnostic differentiation from diabetic oculomotor mononeuropathy, preservation of ocular infraduction is a useful examination. In patients with medial and inferior rectus muscle sparing oculomotor fascicular paresis, physicians should consider the presence of an MLF lesion. It is important that emergency physicians be aware of the possibility of MLF infarction when examining patients that present with clinical oculomotor paresis. We would like to emphasize that performing a careful and detailed physical examination is an essential aspect of clinical assessment for the diagnosis of MLF infarction because of its difficult identification by DW-MRI. Imaging control should be performed in case of ambiguity.

Informed Consent: Due to the identity of the patient can not be defined, informed consent is waived.

Peer-review: Externally peer-reviewed.

Author Contributions: Concept - E.S., E.N.; Design - E.S., B.G.; Supervision - A.Ö., B.G.; Resources - E.S., A.Ö., E.N.; Data Collection and/or Processing - E.S., E.N., B.G.; Analysis and/or Interpretation - E.S., E.N., B.G., A.Ö.; Literature Search - B.G., E.N.; Writing Manuscript - E.S., A.Ö.; Critical Review - E.S.

Conflict of Interest: No conflict of interest was declared by the authors.

Financial Disclosure: The authors declared that this study has received no financial support.

Hasta Onamı: Hastanın kimliği tanımlanamayağından hasta onamı alınmamıştır.

Hakem Değerlendirmesi: Dış bağımsız.
Yazar Katkıları: Fikir - E.S., E.N.; Tasarım - E.S., B.G.; Denetleme - A.Ö., B.G.; Kaynaklar - E.S., A.Ö., E.N.; Malzemeler - E.S., H.M.; Veri Toplanması ve/veya İşlemesi - E.S., E.N., B.G.; Analiz ve/veya Yorum - E.S., E.N., B.G., A.Ö.; Literatür Taraması - B.G., E.N.; Yazıyı Yazan - E.S., A.Ö.; Eleştirel İnceleme - E.S.

Çıkar Çatışması: Yazarlar çıkar çatışması bildirmemişlerdir.

Finansal Destek: Yazarlar bu çalışma için finansal destek almadıklarını beyan etmişlerdir.

\section{References}

1. Disorders of Eye Movements. Part V. Prenuclear Disorders: Brainstem. ii. Internuclear ophthalmoplegia (INO) contributed by Jason J S Barton, University of British Columbia, May 2008 [online] 2016 [cited 2016 May 29]. Available from: http://www.neuroophthalmology.ca/textbook/disorders-of-eyemovements/v-prenuclear-disorders-brainstem/ii-internuclearophthalmoplegia-ino.

2. Stejskal E, Tanner J. Spin diffusion measurements: spin echoes in the presence of a time-dependent field gradient. J Chem Phys 1965; 42: 288-92. [CrossRef]

3. Tamhankar MA, Biousse V, Ying GS, Prasad S, Subramanian PS, Lee MS, et al. Isolated third, fourth, and sixth cranial nerve palsies from presumed microvascular versus other causes: a prospective study. Ophthalmology 2013; 120: 2264-9. [CrossRef]

4. Bolanos I, Lozano D, Cantu C. Internuclear ophthalmoplegia: causes and long-term follow-up in 65 patients. Acta Neurol Scand 2004; 110: 161-5. [CrossRef]

5. Eggenberger E, Golnik K, Lee A, Santos R, Suntay A, Satana $\mathrm{B}$, et al. Prognosis of ischemic internuclear ophthalmoplegia. Ophthalmology 2002; 109: 1676-8. [CrossRef]

6 Kim JS. Internuclear ophthalmoplegia as an isolated or predominant symptom of brainstem infarction. Neurology 2004; 62: 1491-6. [CrossRef]

7. Ksiazek SM, Slamovits TL, Rosen CE, Burde RM, Parisi F. Fascicular arrangement in partial oculomotor paresis. Am J Ophthalmol 1994; 118: 97-103. [CrossRef]

8. Rabadi MH, Beltmann MA. Midbrain infarction presenting isolated medial rectus nuclear palsy. Am J Med 2005; 118: 8367. [CrossRef]

9. Johkura K. Examination of eye movements. Neurol Med 2009; 70: 1-7.

10. Volpe NJ, Lee AG. Do patients with neurologically isolated ocular motor cranial nerve palsies require prompt neuroimaging? J Neuroophthalmol 2014; 34: 301-5. [CrossRef]

11. Jawad RA, Rana AI, Sultan F, Saeed MA. Bilateral medial medullary infarction: a case report. J Pak Med Assoc 2013; 63: 3879. 